\title{
Life during wartime: aspirational kinship and the management of insecurity
}

\author{
Mike McGovern University of Michigan
}

\begin{abstract}
This article explores the ways that the institution of the avunculate has been used as an idiom for negotiating forced displacement, dispossession, and insecurity in the forested region where modern-day Guinea, Liberia, Sierra Leone, and Côte d'Ivoire converge. The essay analyses the ways that the rights and responsibilities that inhere in the MB-ZS relationship are both invoked 'aspirationally' by those with no prior link of kinship and parried by those who should in principle be bound by them. This degree of play suggests that the avunculate in this region is best understood as one of several idioms used to legitimate claims made on others, often in times of uncertainty and instability. Rather than treat this relationship as an always-already existing social institution, the article suggests that it is also the product of a historical experience of persistent warfare, displacement, and flight.
\end{abstract}

How does a refugee manage her arrival in a village where she knows no one? When talking with Loma-speakers in southeastern Guinea about the ways that people are related to one another, men in particular often refer to the institution of Mother's Brother-Sister's Son ( $k \varepsilon k \varepsilon$-daabe) relations to explain their mutual rights and responsibilities. However, as I describe below, these ostensible rights and responsibilities are flouted or cancelled out as often as they are respected. Meanwhile, the stranger arriving in a new village might at first seem to be excluded from such pre-existing relations. However, it is in its aspirational and negotiable mode that the $k \varepsilon k \varepsilon$-daabe relationship may be most predictably enacted. It is paradoxically this same $k \varepsilon k \varepsilon$-daabe idiom that has been historically used by weaker autochthones to try to bind powerful conquerors to themselves by granting conquerors the symbolic legitimacy (and the attendant responsibilities) that comes with becoming 'owners of the land'.

We are thus faced with a situation in which the idiom of the avunculate is used to incorporate both powerless refugees and powerful conquerors. This paradox suggests that the institution, while articulated in discursive terms as being the product of past marriage alliances and relations of descent, is as a matter of practice something different. It is these things, but it may also be part of a 'toolkit', developed over many centuries of recurrent insecurity and unpredictability caused by slave-raiding warfare, colonial military conquest, and the recent regional wars, for managing and negotiating such uncertainty, forced movement, and dispossession. 
This article has three interlinked goals. First, it makes a contribution to the literature on Mother's Brother-Sister's Son (henceforth MB-ZS) relations, a perennial subject of interest in social anthropology over the past century (Bloch \& Sperber 2002; Goody 1959; Radcliffe-Brown 1952). Here I argue that the $k \varepsilon k \varepsilon$-daabe relationship provides an idiom that is a weapon both of the weak and of the powerful, and that it can do multiple (and even contradictory) types of work simultaneously, but that the kinds of essential social negotiations it facilitates are often most tangible in the situations where the $k \varepsilon k \varepsilon$-daabe relationship being invoked has yet to exist. It is an ideal to which one or both parties aspire. Secondly, the essay contributes to the literature on the ways that people attempt to cope with, manage, and make sense of violent upheavals in their lives caused by war and other forms of violence (e.g. Coulter 2009; Finnstrom 2008; Jackson 2004). Placing the discussion of kinship and marriage alliance within the context of violent disruptions forces us to consider the possibility that relations like the avunculate in southeastern Guinea are not products of peacetime social life that are dissolved by the ruptures of war, colonial forced labour, or famine, but perhaps just the opposite. They may have been born under circumstances of, and precisely to assist in the management of, disruption and insecurity. Thirdly, I use several ethnographic examples from my fieldwork to demonstrate the mechanisms by which both individuals and communities have invoked, performed, and reinvented the institution of MB-ZS relations during times of social stress over the past 150 years or so.

\section{Background}

Lomagui is a southwestern Mande language spoken by about 400,00o people split more or less evenly by the Guinea-Liberia border. The language is related to Kpellewo (called Guerze in Guinea), Bandi, and Mendeyei, and speakers of these languages have been characterized in the classical ethnographic literature as politically decentralized and having men's and women's power associations known generically as the Poro and Sande. Loma-speakers in Macenta prefecture, Guinea, and Lofa county, Liberia, live alongside speakers of Maninkakan, known in Macenta as Manyas and in Lofa as Mandingos.

The literature on this region has emphasized that although kinship ideology is patrilineal, strong cognatic tendencies exist alongside patrilineal descent and inheritance, resulting in situations in which the MB-ZS relationship is in some realms more significant than the Father-Son relationship (Leopold 1991; Murphy \& Bledsoe 1987). Like descent ideology, autochthony is an ostensibly fixed logic of identity that is in fact negotiable and fluid (McGovern 2004; cf. Geschiere 2009; Sarro 2009). In the region where Guinea, Liberia, and Sierra Leone meet, autochthony is rendered flexible by its articulation through several idioms, including MB-ZS relations and exogamous clan names that translate across ethnic groups. ${ }^{1}$ The interplay of MB-ZS relations and firstcomer-latecomer relations is the subject of this article. I show how they can facilitate a recalibration of identities that brings the realities of domination and flight into line with immaterial hierarchies of symbolic legitimacy. In this way, communities can transform their conquerors into autochthones, while refiguring themselves as 'nephews'. They can also turn refugees into valuable clients by giving them a language they may use to make kin-like claims on would-be hosts. However, as I describe below, this system is strongly gendered, and women may find it less useful than men. 
An overview of autochthony in Macenta prefecture

The fundamental basis of political legitimacy in Loma politics is autochthony. Those recognized as firstcomers in a village or region enjoy privileged relations with the earth and ancestral spirits that are understood to make successful human and agricultural reproduction possible. In this context, the enactment of sacrifices to these spirits constitutes a renewal of the social compact that recognizes the owners of the land as the legitimate intermediaries between the humans and the spirits of that village. Loma villages where I have lived or visited all have designated village $k \varepsilon k \varepsilon$ (talcke or simply takenui) and village daabe (talaabe) lineages. The talkke lineage is the group of descendants of the village's founder, ${ }^{2}$ and the talaabe lineage is the group of descendants of the second adult male to arrive and settle alongside the founder, receiving a wife from the first-arriving founder. This use of the $k \varepsilon k \varepsilon$-daabe idiom wraps the ideology of kinship and marriage alliance around the ideal of autochthonous political prerogative.

According to Loma notions of land tenure, the first settler in an area (Bhawulanui) is the local landowner (zukenuiltijizamayati). All those who come after him must 'borrow' the land from him or his descendants (Currens 1972). A village or chiefdom founder is the first person to borrow land from the inegiti earth spirits who inhabit it before humans settle in. This zukenui in turn lends a part of the land to which he has gained use rights from the earth spirits to a second-settling man, to whom he also, in principle, gives a wife. The descendants of these two are in a $k \varepsilon k \varepsilon$-daabe relation, and they also are town owners and town sacrificers, all other things being equal. Each of these families, if the village prospers, lends portions of its territory to other newcoming settlers, and over time these newcoming families (who become the landowning lineages within each of a village's quarters) welcome their own clients/strangers/daabe. Families that settle in a village acquire de facto rights to the land they have cleared and cultivated for several generations, and newcomers can ask to use a plot from their portion of the village's land. ${ }^{3}$ In principle, any part of the land can be revoked by the village's landowning lineage. In practice, however, over the course of several generations, a lineage's de facto rights harden into customary boundaries, usually demarcated by streams or other features in the landscape.

\section{An overview of keke-daabe relations in Macenta prefecture}

If autochthony is the language of political legitimacy in a village or town, the language of the avunculate cuts diagonally across it, linking individuals and lineages in a variety of ways. Keke-daabe is the prime idiom of complementary yet hierarchical relations in Loma society (Leopold 1991). In order to make the discussion of ethnographic material later in the article more comprehensible, it is worth describing a range of five interlinked articulations of the $k \varepsilon k \varepsilon$-daabe relation.

\section{Mother's Brother to Sister's Son}

This is one of the key instances of the idiom and ordinarily trumps the others. The actual, biological relationship between a man and his mother's brothers renders them unquestionably and irrevocably kekenuiti and daabenuiti ('Mother's Brother's people' and 'Sister's Son's people'). With men, this relation may carry on across an indefinite number of generations, especially if the relation is reiterated through the related roles of wife-giver to wife-receiver. 
It is particularly in the context of the literal Mother's Brother-Sister's Son relation that one sees some of the prototypical rules that apply to $k \varepsilon k \varepsilon$-daabe etiquette. A daabe must always, for instance, take off his hat in the presence of his $k \varepsilon k \varepsilon$. Not to do so is a grave offence, and can bring a malediction. Conversely, the daabe can take any item belonging to his 'uncle' (cf. Goody 1959). The $k \varepsilon k \varepsilon$ also owes his daabe land to farm and a house to live in. In theory, one of a young man's Mother's Brothers should see to the arrangement of his marriage, preferably to a young woman from the $k \varepsilon k \varepsilon$ lineage. Given the ideology of patrilineal equivalence, this amounts to the Mother's brother giving his daughter (who might also be his Brother's daughter, Father's brother's son's daughter, or Son's daughter) to his Sister's Son. In reality, such marriage prescriptions are only sometimes followed (Leopold 1991: 347). When they are followed, they constitute the next aspect of the relation.

\section{Wife-giver to wife-receiver}

Another facet of the $k \varepsilon k \varepsilon$-daabe relation is that between people who are related as Father-in-law and Son-in-law. Their long-term relation has been cemented by the 'exchange' of a woman (the $k \varepsilon k \varepsilon$ 's daughter, the daabe's wife). From a woman's point of view, this is the relation between her husband and father. The relationship extends categorically so that all the members of the wife's father's patrilineage stand in the relation of kEkEnuiti to the wife-receiving young man, and whether or not there had been literal Mother's Brother-Sister's Son relations between the two lineages before, they are now related as kekenuiti and daabenuiti.

In principle, this relation travels down the patrilateral line as a form of perpetual kinship. In practice, unless the link between wife-giver and wife-receiver is reinforced, it may fade. It is ultimately cemented by the birth of sons, who become the Sisters' Sons of their wife-giving matrilateral kin. This is the basis of the linkage between the MB-ZS and the wife-giver to wife-receiver facets of the idiom. At any point where there are no subsequent unions between the two lineages that produce mature sons, that link may disappear, unless the relationship is maintained within yet another of its permutations, such as that between sacrifiant and sacrifiteur.

\section{Sacrifiant to sacrifiteur}

Standing alongside the first two facets of the idiom is that of sacrifiant to sacrifiteur. ${ }^{4}$ While kekenuiti provide their daabenuiti with women to marry, land to plant, and other goods, daabenuiti act as intermediaries for their 'uncles', especially by performing sacrifices on their behalf. These sacrifices may be for the welfare of an individual or family (during a funeral, to help a woman conceive a child, or to help a child pass an exam), or they can be for the sake of an entire lineage or village.

I never heard of an instance of the sacrificial relationship spawning $\mathrm{MB} / \mathrm{ZS}$ or wife-giver/wife receiver relations. Because it stands alone as a product of and not a source of $k \varepsilon k \varepsilon$-daabe relations, it is considered strong proof of a solid, pre-existing $k \varepsilon k \varepsilon$-daabe link. The sacrifiteur, who performs a sacrifice for the sacrifiant, stands already in a daabenui relation to him. In the case of an important sacrifice, Lomaspeakers always (in my experience) found a man who stood in a daabenui relation to them to serve as sacrificers. ${ }^{5}$

\section{Owner of the land to newcomer}

This relationship of (relative) autochthony is an area often described by Loma-speakers using the encompassing $k \varepsilon k \varepsilon$-daabe idiom in a way that combines a discussion of 
autochthonous rights, marriage alliance, and ritual/sacrificial relations. As already mentioned, the lineage of the putative village founder is considered the 'town Mother's Brothers' (talcke), while the lineage of the second arrival is the town daabe lineage. Similarly, the lineage of each subsequent arrival in the village stands in a hierarchical $k \varepsilon k \varepsilon$-daabe relation to the lineage of the household head who first welcomed them. This highlights the diachronic aspect and built-in fragility of any $k \varepsilon k \varepsilon$-daabe relationship. These $k \varepsilon k \varepsilon$-daabe relations are usually linked to a description of the past, and may serve as a kind of historical charter (Malinowski 1992 [1948]) for the contemporary political dispensation. We will see in the third ethnographic example below the kind of work the $k \varepsilon k \varepsilon$-daabe idiom can do in bringing the necessities of realpolitik into line with the symbolic economy of legitimacy.

\section{Host to stranger/guest}

This facet of the $k \varepsilon k \varepsilon$-daabe relation is the pre-eminent aspirational use of the idiom, and is closely related to the landowner/newcomer relation. Any stranger (mawai/wèe) zamai) coming into a Loma-speaking village must establish a relationship with a host (nianke/nowaikea). ${ }^{6} \mathrm{New}$ arrivals establish such a relationship with a host, normally an adult man who is the head of a household (though not necessarily of his lineage). The newcomer gains access to land, a place to build a house, and the host gains wealth-inpeople. ${ }^{7}$ Virtually all adult Loma-speakers in villages grow upland (swidden) rice. During the agricultural cycle, there are labour bottlenecks, and in this sparsely populated region, only someone who can marshal a large work party can hope to make a large rice farm. Clients, family, and stranger-guests are all integral to the production of a household's wealth. ${ }^{8}$ Heads of Loma households assume that all members and clients will make themselves available for such work upon request, an assumption that frees them to cultivate less guaranteed networks of mutual support, like co-operative work groups (cf. Bloch 1973). Such support is also important in the context of village politics, as a man without a sizeable contingent 'behind' him is relatively powerless (Murphy 1990).

In the context of $k \varepsilon k \varepsilon$-daabe relations, it is important to note that the relationships between hosts and strangers are usually not between literal Mother's Brothers and Sisters' Sons, or Fathers-in-law and Sons-in-law. They may be acquaintances, age mates, or virtual strangers, perhaps linked by a mutual friend. Although the relationship may use the $k \varepsilon k \varepsilon$-daabe idiom in an informal way, the $k \varepsilon k \varepsilon$-daabe relationship is only literally established after the fact of initial co-operation and mutual assistance.

This situation can be confusing for the outsider, because actors are likely to use the language of mutual (and ostensibly pre-existing) obligation invoked by $k \varepsilon k \varepsilon$-daabe relations, even for recent collaborations. For instance, one of the terms for host, 'nowaikea', literally means 'the father of my girlfriend', or 'the father of my prescribed wife' - in essence, 'my $k \varepsilon k \varepsilon$ '. The implied link is between hosting and cementing the relationship with a marriage alliance.

\section{Social authorship under conditions of uncertainty}

This fact is extremely important, in the context of my overarching argument about the ways that people in the region have managed disruption, because it is how the $k \varepsilon k \varepsilon$-daabe idiom has facilitated the absorption of strangers. It has allowed ethnic identity and social distance to be downplayed in favour of real-time co-operation and reciprocity, which may develop over time into links ratified by the local ideology of 
kinship and marriage alliance. The stranger-host relationship allows such transformations through its emphasis on social action: I go to help you harvest your rice today, you present me with a plot of land to cultivate next year; I tap a palm wine tree and bring you a cup of wine every day for three months, you ask me to sacrifice a

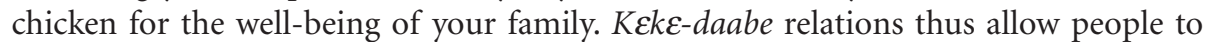
evaluate where they stand in relation to one another; not just through a system of roles and statuses given to them, but through a system of reciprocal relations that put roles such as wife-giver or host into motion within a social and ethical system of hierarchical complementarity.

Such a dynamic forces us to consider a particular aspect of village micropolitics. There are likely to be several failed would-be alliances for every one that endures to the point where it is cemented by marriage and kinship. Strangers who end up being rude, ungrateful, or simply moving on yet again might have been classed briefly as daabenui, but are soon recategorized as having been nothing more than visitors, opportunists, or perhaps visiting researchers. The system of $k \varepsilon k \varepsilon$-daabe reciprocity is fluid, but it inscribes itself only on those 'successful' social relations that conform to its rules. At the same time, by its very definition of terms, it erases failed attempts at alliance from the historical-social record.

The history of anthropological discussion of the MB-ZS relation is long and a full analysis of it is beyond the scope of this essay. However, most approaches share one characteristic: from Bachofen's (2008 [1861]) Mutterrecht thesis, adopted by evolutionist anthropologists, to Radcliffe-Brown's (1952) sociological rejection of the notion that MB-ZS intimacy was a survival from the matriarchal past, to Goody's (1959) synthesis of a sociological analysis with a political-economic attention to the 'domestic mode of production', and finally to Bloch and Sperber's (2002) account of MB-ZS relations as a cognitive orientation explainable by the evolutionary advantages afforded by altruism towards close relatives, all these treat the avunculate as an institution. The clear disadvantage of such an approach, as I hope to show in the rest of this essay, is that it mixes together two things that are not just separate, but in fact serve virtually opposite ends. The stereotyped banter, snatching of the uncle's possessions, and joking relationships that were of particular interest to Radcliffe-Brown, for instance, undoubtedly exist in many settings (including amongst Loma-speakers), but their socio-political significance is often quite minimal. As Bloch and Sperber have correctly noted, there is reason to be sceptical that the ZS's licence to take his MB's goods has significant redistributive consequences, 'as opposed to being a topic of conversation with occasional symbolic enactments, serving to define social roles rather more than to reallocate economic resources' (2002: 733).

This is not to say, however, that the MB-ZS relation is never central to socio-political negotiations that may bear directly on matters of life and death. I describe several below. What is different here is that even though the discourse of $k \varepsilon k \varepsilon$-daabe relations is invoked or used instrumentally, it usually does not refer to pre-existing MB-ZS or wife-giver-wife-receiver relations. It is for this reason that I refer to $k \varepsilon k \varepsilon$-daabe as an idiom, rather than as an institution.

The ethnographic examples that follow demonstrate some of the ways that the avunculate has served Loma-speakers and neighbouring ethnic groups as a flexible idiom for managing failure, defeat, and disruption. The attempt to assert forms of weak control over defeat and dispossession requires a complex set of tactics for managing knowledge in order to bring the requirements of actually existing power relations into 
line with local ideologies of autochthony, alliance, and descent. We might think of these tactics as a repertoire for asserting social authorship under conditions of severely mitigated agency.

Researching MB-ZS relations in these circumstances raises a methodological problem, because while people are often keen to engage in the banter and joking that characterize the banal face of this relationship, they may be equally keen to dissimulate the instances in which idioms like $k \varepsilon k \varepsilon$-daabe have been used with high stakes. Though different, this issue presents a comparable methodological and analytical problem to that described for the 'mutedness' of gender in Ardener's discussions of 'Belief and the problem of women' (1975). We shall see such a process of 'muting' in the third ethnographic vignette below. Commenting on the aid provided in such endeavours by shallow lineages among Kpelle, ${ }^{9}$ Murphy and Bledsoe write that, it is clear that genealogical amnesia is less a matter of faulty memory and more one of strategic reconstruction that defines and redefines as pivotal those events that best legitimize the new political arrangements' (1987: 133). This is an insight that was originally offered by Warren d'Azevedo, whose article 'Uses of the past in Gola discourse' (1962) is a founding text on the sociology of knowledge in the Upper Guinea Coast region. D'Azevedo describes the way that Gola chiefdoms (to the southwest of the Loma) absorbed both conquerors and supplicants displaced by warfare. As he points out, public discourse on the history of lineages' relations to one another, and their relation to the contemporary state of a village's political hierarchy, is quite different from the discussions taking place behind closed doors.

The management of knowledge and the tight control over its enunciation point us towards an irony: the work of social authorship I have just described may operate as often via chosen or enforced silences as through articulation. ${ }^{10}$ The third ethnographic case described below is an exception that proves this rule. ${ }^{11}$ It also points to what I consider one of the primary motivations for the silence surrounding such histories of conflict and domination: the defeated would have little to gain from pushing their claim to landowner status. Indeed, the disjuncture between their symbolic rights as firstcomers and their current conditions as powerless lineages in local politics would only emphasize the fact that their history was one of failure and decline. In these silences, we witness the tricky politics of managing failure: better to bind your potential conquerors to you, still retaining a bit of symbolic importance, than to find yourself annihilated or enslaved.

The $k \varepsilon k \varepsilon$-daabe idiom thus builds on the cultural ideal of autochthony, and is the primary Loma model of hierarchical relationality - between individuals, lineages, and ethno-linguistic groups. It has also framed Loma-speakers' struggle to manage domination and dispossession. Although it might seem to an outside observer that the substitutions and elisions between the different facets of the $k \varepsilon k \varepsilon$-daabe idiom are purely instrumental and strategic undertakings, it is not so simple. Because Lomaspeakers cultivate ambiguity and indeed confusion in the field of kinship relations, it is easy to understand the extension between, for instance, an aspirational facet of the $k \varepsilon k \varepsilon$-daabe relation (e.g. host to stranger) and one of its more concrete manifestations (e.g. wife-giver to wife-receiver). It is simultaneously instrumental at the behavioural level and naturalized within the cognitive model of proper uncle-nephew relations. This duality is made possible by the inveterate "slippage" or "dissonance" (Wagner 1977: 633) in the uses of the $k \varepsilon k \varepsilon$-daabe idiom. At this point, I turn to a series of ethnographic examples in order to demonstrate how the principles of this social 
calculus operate in different settings. They range from the banal to matters of life or death, but each sheds light on different aspects of the ways that Loma-speakers combine the principles of autochthony and of $k \varepsilon k \varepsilon$-daabe relations in practice.

\section{Ethnographic example 1: 'Pour me some wine!'}

At the interpersonal level, $k \varepsilon k \varepsilon$-daabe relations are often contested. Anyone who has spent some time in a Loma village quickly notices that almost any two Loma-speaking men meeting for the first time, or indeed for the $n$th time, are able to find a way of asserting that each is the other's $k \varepsilon k \varepsilon .{ }^{12}$ Consider the following exchange I witnessed in 1998 in a Loma village I will call Giziwulu. ${ }^{13}$ Sitting with Taanu and Kôtin $\gamma a i$ drinking some palm wine, Bokassa came along, greeted us, put his hand on Taanu's shoulder, and said, 'Daabe, dôoi pu su', or, 'Daabe, pour me some palm wine'. As was usual in such $k \varepsilon k \varepsilon$-daabe exchanges, the statement was friendly, but issued in the form of a command. In response, Taanu said, 'Gbe?! Ga ya elaabenui?' Expressing feigned shock, he asked, 'Who are you talking to? Me, your daabe?' The discussion continued for a minute or two longer in tones of mock outrage. Bokassa was from Giziwulu's landowning (zukenui) clan while Taanu was from the village's second family, by definition the daabenuiti of Bokassa and his lineage. Conversely, Taanu's paternal grandfather had given his daughter in marriage to Bokassa's father, and thus Bokassa was Taanu's Father's (and by right, also Taanu's) Sister's Son, one of the key instantiations of the $k \varepsilon k \varepsilon$-daabe relation. Each was the other's $k \varepsilon k \varepsilon$, and each was the other's daabe. The discussion soon ended in some wine being poured for Bokassa, and the conversation shifted to other subjects. ${ }^{14}$

Such discussions are usually settled amicably, with one party often admitting to being the 'real' nephew. In this case, while it was true that Bokassa was Taanu's literal Father's Sister's Son, and thus his daabe, the special status of their two clans as the founding taaleke and taalaabe (village $k \varepsilon k \varepsilon$ and village daabe) lineages trumped everything else. The particularity of their actual wife-giver and wife-receiver relation was classed as an anomaly. The means for determining who is the 'real' $k \varepsilon k \varepsilon$ or daabe are situational. I have tried to pin Loma-speakers down on the means for determining the proper hierarchy of instances, but with no luck. Thus the same kind of joking argument may take place between the same men a week later.

This example resembles the kind of link between the avunculate and joking relationships that anthropologists know well from the classic literature of the first half of the twentieth century (e.g. Radcliffe-Brown 1952). More importantly, it also shows how the different aspects of $k \varepsilon k \varepsilon$-daabe relations interact in a laminated fashion so that they nearly cancel one another out in the context of quotidian pleasantries. This has not always been the case, and the following example shows the outcome for one unlucky individual when the complex web of $k \varepsilon k \varepsilon$-daabe relations in a village was activated with more consequential stakes.

\section{Ethnographic example 2: adultery, marriage, and pawnship}

The following passage from my own Loma nowaikea (stranger father) Balla's life history gives a glimpse of how these straightforward principles become woven into the less convivial complications of everyday life. It also provides a picture of the way pawnship worked in southeastern Guinea. These events took place in a village near Giziwulu (described in example 1), but the period was about $1935 .:^{15}$ 
The second time I was pawned, our daabe, Foromo, came back from Liberia. He wanted a certain woman named Kpuode. She was already married, and her husband said to her older brother, 'I am also your daabe, but now you want to take this wife of mine to give to your other nephew?' In order to ask for this woman, my parents went to Gevela and the father to borrow the money. They took six rolls of cottonade [locally hand-loomed cloth, often used in bridewealth payments]. You could make a small boubou [gown] with one of these rolls. We took the cloth with 60 francs. For this, I was pawned again. Every day, I pounded the rice in a mortar, I fetched the water, I carried the wives' head loads. I spent three months there. Even Nyaalewulubo's house was built by me (B.P., 9 May 1999).

Balla described his lineage's nephew's adulterous affair with Kpuode. Both Foromo and the woman's husband were daabenui to the woman's family, and thus prescribed marriage partners. The family 'owed' each a wife, in jural terms, but may have had a limited pool of eligible women. Moreover, it is obvious that both Foromo and the husband wanted Kpuode, not just any woman from the lineage. Here the alliance ideology that treats classificatory kin as perfectly interchangeable founders on the particularities of desire and love.

Most likely this particular case came down to a simple decision. Once the adultery was made public, Kpuode's family probably asked her to go back to her husband and stop the affair with Foromo. When it became clear that Kpuode preferred Foromo, they would have been forced to help negotiate a solution acceptable to everyone. The husband's complaint that he, too, was a daabe indicates that he did not want to part with Kpuode, and perhaps he felt that her family was not doing enough to convince her or force her to stay with him and leave Foromo alone. ${ }^{16}$ The adulterous suitor (Foromo, in this case) would typically have to refund any bridewealth, ${ }^{17}$ and add a fine, paying the husband damages before either the husband or the wife's family would agree to release her. ${ }^{18}$ In this circumstance, Foromo obviously beseeched another of his $k \varepsilon k \varepsilon s$ - that is, Balla's parents - for a loan. They agreed to help him out of his bind (obligated, as they were in principle, to help him find a wife), but had to borrow the money to do so. They had to put Balla into a situation of domestic servitude to guarantee the loan until it was paid three months later. At this point, the family came to redeem (umaawu lit. 'liberate the head') him. In this case, a son was pawned to secure a daabe's bridewealth. Balla's family did not supply a wife, but instead the payment for a wife who came from another

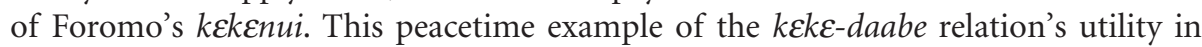
negotiating a contentious social situation shares aspects of example 1's enactment of what Sahlins (2011) has called 'mutuality of being', while at the same time entailing some of the implicit and explicit elements of coercion discussed in the following examples.

\section{Ethnographic example 3: the settlement of Bhilu}

So far, we have seen the ways that an encompassing idiom shared by Loma-speakers is enacted amongst individuals. The following example moves from the micro to the meso level, showing how $k \varepsilon k \varepsilon$-daabe relations were utilized to smooth over potentially deadly rifts between two groups - weak autochthonous farmers and powerful conquering outsiders - in two neighbouring villages. The events described here took place in a chiefdom some 25 kilometres away from Giziwulu, and the events of conquest and the creation of new autochthony probably took place between 1850 and 1875 .

This shared history of two villages that I collected in 1999 gives a picture of the kind of relations that played themselves out in many Loma-speaking villages, where strong 
warriors (kowuluboi) promised to protect weaker landowners (zukenuiti) in return for landowner status. ${ }^{19}$ This was one of the first village histories I ever collected, and everything was confusing and new to me. My host in the village first introduced me to the village chief, a member of the landowning Grovogui clan, and some of his entourage of elders. Then we returned to the house where I was staying, and spoke for a while. My host said,

\begin{abstract}
You know, the Kpakpavogui - who don't eat the leaf that makes one itchy - are the original owners of the land in this area, not the Grovoguis. They [the Kpakpavogui] lived alongside the Sampogui in equality. The Sampogui became their nephews. The Kpakpavogui dreamt of the arrival of certain war chiefs - that was the Grovogui. The Grovogui took over political power because they fought off the Goligbagui ('those who seek and chase'). The Goligbagui were related to the present-day Kono in Sierra Leone (K. S., 6 November 1998).
\end{abstract}

In fact he himself was a member of one of the déclassé lineages he spoke of, and so I took his account in with some scepticism. The next day, while recounting the village's history, the ostensibly landowning Grovogui elder referred to the KpakpavoguiGrovogui relationship in ways that I now recognize as subtly encoded, but which overtly denied Kpakpavogui precedence. He said the Grovoguis 'were the first people to make the village and the chiefdom into a place of importance'. I did not force the issue, but filed the two discrepant versions away in my notebook. Two days later, I walked to a sister village, just 6 kilometres away. When, the next morning, the eldest member of the landowning Grovogui lineage recounted the village history, he described (unprompted) the relationship between the Kpakpavogui and Grovogui lineages:

\footnotetext{
Khologa was the original place where the Kpakpavogui and Grovogui ancestors met. It was hard living where the Grovoguis did, and so they sought a new home. Woniwhoza [Kpakpavogui] was the first person the Grovogui ancestor met. Woniwhoza was afraid. He put a big jar over the smoke of his [cooking] fire, so that no one would see it [its smoke], and he tied his mortar to a tree, so that no one would hear its pounding [reverberated through the ground]. When Grovogui came, he detached the mortar, and took the jar away. But Woniwhoza told Grovogui, 'When my enemies come to attack me, I have no defence but the smell of my farts'. He thanked Grovogui for coming to protect him.

Hearing the reverberations of the mortar and seeing the smoke, the enemies came. The Kpakpavogui ancestors were feeble until the Grovoguis arrived. Yokwei was the Grovoguis' best warrior. He was a fast runner and a good spear-thrower. The enemies came. Yokwei started to kill them, one after another. He chased the rest into a stream, and as they started talking to each other in their flight, it became clear that they were Manyas [a neighbouring ethnic group].

Since the Grovoguis had protected them, Woniwhoza said, 'I will let them rule over my land. Otherwise, the Manya will overrun us'. He told Grovogui, 'What you find to eat here, take it'. His wife said to him, 'You've said too much. You should still have some responsibility over your former domain. Don't give everything away'. He agreed and talked to the Grovoguis, so that now, if the Grovoguis kill an animal, they give the liver to the Kpakpavoguis (T.B.G., 9 November 1998).
}

Here is another version of the same story, given me later in the same village by a different Grovogui elder:

\footnotetext{
The first [Grovogui] ancestor [Yala] came here, and didn't find anybody. He came a second time, found a tapped raffia palm, drank some wine and left an arrow. He came again, this time leaving two arrows. Finally, he met a Kpakpavogui by a banana tree, and shared some of his bean purée with him. Woniwhoza [Kpakpavogui] sent his son to find Yala again, to get fire and more bean purée. The son went, and Yala gave him fire and bean purée. The son liked it, and they sent another ball of it with him
} 
for his father. Woniwhoza liked it, too, and sent his son back again. Again the Grovoguis gave him one ball for himself, one for his father. Finally Woniwhoza said, 'Bring them here; since they are numerous' (T.G., 9 November 1998).

This last version of the chiefdom's settlement history gives a taste of the ways that these narratives become altered over the years so as to efface histories of violence and domination. This narration is a kind of middle position between the first version's outright denial and the second version's outright acceptance of the Grovoguis' rise to dominance by first military and eventually symbolic means. In the third version, the laying down of arrows is a metaphorical acknowledgement of the force that the Grovoguis possessed and the Kpakpavoguis lacked. At the same time, the existence of tapped raffia palms and banana trees acknowledges the fact that the Kpakpavoguis had settled, cultivated, and 'civilized' this area of the country. The pre-eminence of the Grovoguis is hinted at by reference to their possession of 'fire', a common metaphor for symbolic hierarchy amongst chiefdoms in the southern Loma-speaking region. The rest of the story emphasizes the commensality of shared food, but the last sentence, 'Bring them here; since they are numerous', again raises the spectre of the insecurity of life during wartime. The Kpakpavogui ancestor chose to relinquish political control before it was taken away.

The first version, in which the elder stated simply that the Grovoguis 'were the first people to make the village and the chiefdom into a place of importance', implicitly admits the presence of a preceding aboriginal population to the knowledgeable listener, but simultaneously classifies them as insignificant (Murphy \& Bledsoe 1987: 129). In the latter two versions of the Bhilu narrative, the reason why the Kpakpavoguis should be classed as insignificant becomes clear. They settled the territory, but were unable to defend it. Implicit in this narration is the understanding that if the Grovogui warriors had not come along when they did, the Kpakpavoguis would have been annihilated, and whoever did establish military control over the region would have started from zero in their negotiations with the inegiti earth spirits to establish uncontested autochthonous rights.

The micropolitics of negotiating defeat is part of the history of many villages throughout the Upper Guinea Coast. ${ }^{20}$ The $k \varepsilon k \varepsilon$-daabe idiom allowed the absorption of strangers of many backgrounds according to the specific history and political arrangements of each chiefdom. This example gives a rare glimpse into the process by which relatively weak owners of the land tried to bind powerful newcomers to them. The stakes in such instances were raised still higher than in the case of Balla, who was pawned. In the days of inter-village raiding in this region, conquered populations often risked enslavement, forced marriage, or simply death. By turning conquerors into landowning 'uncles', communities offered an aspirational vision of the future. By offering the fiction of landowner status to the lineage of a conqueror, Loma-speakers offered the political-symbolic legitimacy that such status - and the attendant rights as enacted through sacrifice to the earth spirits - represented. At the same time, such an offer presupposes an aspirational relationship that would bind warlords to their subjects through relations of reciprocity. This reciprocity was undoubtedly hierarchical and still favoured the conquerors. Moreover, those who held the political and military upper hand could always renege on these reciprocal relations with relatively fewer social penalties. However, any former warlord with an interest in living his days out in relative peace might find the bargain attractive. ${ }^{21}$ 
Ethnographic example 4: violence, forced migration, and keke-daabe relations

The $k \varepsilon k \varepsilon$-daabe relation has been shaped by the persistent insecurity that Loma-speakers have experienced over the past 150 years, and possibly much longer. ${ }^{22}$ Historical contingency has necessitated behaviour that in turn helped shape Loma cultural ideals such as autochthony and asymmetrical complementarity. This is not, however, a bridge that we shall cross in one direction only. While events, some of which were violent, have likely shaped institutions, the influences have been reciprocal, and institutions have also shaped Loma-speakers' negotiations of concrete situations. It is for this reason that I choose to call the $k \varepsilon k \varepsilon$-daabe relation an 'idiom', so as to underline the dialectical and flexible relationship involved. One situation in which Loma-speakers invoked the $k \varepsilon k \varepsilon$-daabe idiom was the arrival of hundreds of thousands of forced migrants from Liberia during the 1990s. One such person, living in a farming hamlet within the territory of Giziwulu, was Mary.

Mary was a Kpelle-speaker from Liberia, displaced by the war that began on Christmas Eve, 1989. Like most Liberian refugees, she chose to settle in an existing Guinean village, rather than a UNHCR-managed camp. ${ }^{23}$ Like a significant number of refugee women, she married a Guinean man. In this case, her husband was my doma, the man in the village who shared the same Loma name and with whom there is often a presumption of familiarity and intimacy. As it happened, we did enjoy one another's company, and so I visited them every few weeks at their hamlet about two hours' walk into the bush from the village. Mary was, like her husband, exceptionally hard-working. By building a permanent house in the bush, they were able to work long hours in their rice field, their cocoa and coffee plantations, and in Mary's garden, thus producing a significant surplus. Mary used the proceeds of this agricultural production to buy trade goods, and over the five years or so that she had been married to my namesake, the range of her trading had grown increasingly large. Indeed, by the time I first met her, she was taking advantage of the brief period of peace that followed Charles Taylor's election as Liberia's president to re-establish links in Liberia, and to trade goods between Guinea and her home country.

Unlike many other refugee women, Mary did not return to Liberia, but remained married to her Guinean husband, considering Giziwulu her home. Her first husband had been killed in the war, and she had also lost one of her children to illness. I had the sense that Liberia was a place with too many painful memories for her to want to return to, and in any case, she had built a good life for herself in Giziwulu. As a woman, she was not embedded in the $k \varepsilon k \varepsilon$-daabe system in the same way that men were. Interestingly, though, she several times made reference to the fact that her kekEnuiti the Loma had welcomed her, as was their duty. This was playing on yet a further use of the idiom, which refers to entire ethnic groups as standing in a $k \varepsilon k \varepsilon$-daabe relationship to one another. In effect, it is a way of stating autochthonous precedence, with the $k \varepsilon k \varepsilon$ ethnicity acknowledged as the firstcomers, and the daabe as the latecomers. In this regard, Loma always acknowledged Kissi-speakers as being $k \varepsilon k \varepsilon$, in their present area before the arrival of Loma-speakers from the northeast, just as they always insisted that Manya/Mandingo populations were the nephews of the Loma, having arrived more recently. The relationship between Loma and Kpelle was much less clear, with some insisting that it was the Loma who were $k \varepsilon k \varepsilon$, and others that it was the Kpelle. Still others hedged, suggesting that it depended on the villages in question. As Giziwulu sat directly on the boundary between the Kpelle- and Loma-speaking regions of Guinea, it 
was significant that Mary chose to emphasize her status as an ethnic daabe. This was one way of making a claim on a community in time of need, and finding the language that could help make the claim stick.

Mary's situation and her successful negotiation of refugee vulnerability with a little help from the $k \varepsilon k \varepsilon$-daabe idiom points towards some of the ways that the idiom is highly gendered, and operates in more flexible ways for women than for men. ${ }^{24}$ Listening to the ways that adult Loma-speaking men talk about the relation, we might primarily imagine a web of inherited $k \varepsilon k \varepsilon$-daabe relations, implying a set of jural rights and responsibilities that outline a map of the social network into which a Loma person is born. However, against that inherited web is the network of relationships that the same person builds him- or herself, whether out of preference, friendship, accident, or pure strategization. This network may undercut certain aspects of the inherited one, and it may create new rights and responsibilities that occupy much of that person's time and energy, and are later passed down to her or his descendants.

The tendency towards created and away from inherited networks is easier to see among women than men. Though the masculine ideology of kinship and marriage in Loma-speaking villages is that women are exchanged by men so as to cement their alliances, this can often appear as wishful thinking, as women are in fact quite mobile and exercise significant choice in their selection of spouses and lovers (Bledsoe 1980). One of the factors facilitating women's strategies is the fact that kinship ties in patrilineal societies have (by definition) an ambiguous hold on women. ${ }^{25}$ A Loma woman passes on her own patrilineal kinship ties to her children as $k \varepsilon k \varepsilon$-daabe relations. But travelling up the matrilateral line, it is only her mother's kin, and perhaps her father's mother's kin, who will be able to make any claims on her. Because women are ideologically 'detachable' from the lineage, these ties are far weaker than they would be for her brothers. She is thus relatively freer to establish relations of her own, and ones that may be more to her benefit than those she has inherited. Like Mary, many female refugees simply married Guinean men.

At the same time, aspirational $k \varepsilon k \varepsilon$-daabe relations are fragile because either party may opt out of them with few social costs. Someone making a claim on a commonly recognized $k \varepsilon k \varepsilon$, for instance, can perhaps be evaded (with delicacy), but cannot be refused outright. Alternatively, someone making a claim on a friend and would-be $k \varepsilon k \varepsilon$ may be met with a simple shrug of the shoulders and a 'Sorry'. Nothing more than the friendship is at stake, and a third person is less likely to intercede on behalf of the friend, the way that a dozen people would immediately do on behalf of a 'real' (i.e. longstanding) $k \varepsilon k \varepsilon$ or daabe.

This is the situation described by Maurice Bloch (1973) in his essay 'The long term and the short term: the economic and political significance of the morality of kinship'. In it, he describes the way that Malagasy peasants cultivate friendships while neglecting their kin. When the chips are down, kin must come to your aid. Friends will do so only if it suits them, and if your prior assistance obligates them. As Bloch describes, this dynamic is especially pertinent in the Malagasy rice-farming agricultural cycle, which is subject to the same kinds of labour bottlenecks as the Loma one. They require a person to marshal both personal and kin networks. Neither one will suffice by itself. Thus Loma-speakers with small inherited networks of $k \varepsilon k \varepsilon$-daabe relations, or with few strong personal relations, are not just socially isolated, but also doomed to a perpetual cycle of bare subsistence. They will probably never be able to plant rice farms big 
enough to create the kinds of surpluses that can be translated into wealth-in-people, or a workforce that can create still bigger surpluses.

\section{Conclusion: the peace mirage}

This article has proposed a slightly different approach to the 'controversy' surrounding the MB-ZS relationship. Most prior approaches have assumed that the avunculate was an institution and, as such, they sought its origins. Starting from the understanding that the avunculate was an institution that preceded and thus subsumed the individuals who enacted it, they understandably sought the first principles that could explain its emergence.

For Loma-speakers, I think it is undoubted that $k \varepsilon k \varepsilon$-daabe relations do exist in an institutional form. Pre-existing $k \varepsilon k \varepsilon$-daabe relations do matter in settings ranging from casual banter to the selection of a sacrifiteur for an important ritual. Moreover, there is a variable, but statistically more than negligible marriage pattern by which $k \varepsilon k \varepsilon$-daabe also forms the basis of prescriptive marriage alliances, à la Lévi-Strauss. At the same time, I have tried to show that the highest-stakes uses of the relationship may be in situations where the $k \varepsilon k \varepsilon$-daabe relationship is aspirational and does not predate its invocation. In this regard, we see $k \varepsilon k \varepsilon$-daabe as being both institution and structuring discourse. However, the part of the relation that has ensured the continuing usefulness of $k \varepsilon k \varepsilon$-daabe over time may well not be its institutional characteristics. Thus seeking to work inductively backwards from $k \varepsilon k \varepsilon$-daabe and similar instances of the avunculate to discern their true roots may yield unsatisfactory (not to say incommensurable) results.

The most acute instances of usefulness of $k \varepsilon k \varepsilon$-daabe relations for Loma-speakers exist in the forward-looking, as-if situations where people invoke the idiom in order to save their own lives. As I have suggested, many such partnerships will invariably dissolve, and never reach the stage of becoming 'real' $k \varepsilon k \varepsilon$-daabe relations, cemented by generations of intermarrying cross-cousins and sacrifiant/sacrifiteur relations. This is the fluid, mutable territory of wife-givers and wife-receivers described by Leach in Political systems of highland Burma (1954), a situation whose explicit political stakes have recently been clarified in Scott's The art of not being governed (2009). The Upper Guinea Coast is certainly a kindred sort of 'West African Zomia'. The marriage alliances and uncle-nephew relations one finds in Loma-speaking villages thus suddenly appear less as the solid institutional framework of interpersonal and micropolitical relations (which is certainly the way adult men talk about it), and more as the traces of past negotiations, many of them struck on the fly, often when at least one partner to the relation was operating under conditions of real danger or precarity.

This material thus leads us to resist easy distinctions between peaceful (normal) and violent (aberrant) lifeworlds. Instead, it encourages us to look at the ways that Lomaspeakers have made sense of and through violence, used it tactically, and attempted to bind and manage it over the longue durée, during which periods of persistent conflict have been more the norm than the exception. How, even in the face of massive disruption, do Loma-speakers manage to continue the productive and reproductive activities essential to the continuation of life once peace has returned, and how are these strategies linked to a historical experience of recurrent insecurity over the last 500 years? I suggest the possibility that during this centuries-long period when conflict, displacement, and uncertainty were persistent though not constant, the practices and idioms we know from $c .1850$ onwards were taking shape. 
These questions highlight a kind of 'peace mirage'. Scholars working from 1950 to 1990 produced a superb body of scholarship on the Upper Guinea Coast region. However, they tended to treat the 'tribal wars' of the nineteenth century and before as something long-gone, and not necessarily integral to social relations in the twentieth century. If we look at these disruptions, forced migrations, and related coping mechanisms as partly constitutive of Upper Guinea Coast social idioms and practice, the peace that characterized the 1910 to 1990 period appears as one moment in a long-term oscillation. In this way, wartime disruption may give us clues about the longevity of certain peacetime idioms, even while those same idioms can be seen in a new light, as the modalities used by those in peril yet aspiring to greater stability and predictability.

\section{NOTES}

The research on which this article is based was conducted in Guinea between September 1997 and March 2001. I gratefully acknowledge funding from the Social Science Research Council, the MacArthur Foundation, a Fulbright-Hays Fellowship, and the Harry Frank Guggenheim Foundation. I also thank Bernard Bate, Siba Grovogui, Corinne Kratz, Paul Richards, Douglas Rogers, Ramon Sarro, and three anonymous reviewers for their constructive criticism and advice.

This article was originally dedicated to Ivan Karp, my graduate mentor, on the occasion of his retirement. Sadly I now have to dedicate it to his memory. Were it not for him, I would never have asked the questions that led to this article, and I'm glad he had the chance to read it, prompting a characteristically productive exchange, about two months before his untimely death.

${ }^{1}$ The translatability of ethnic identity across the region via equivalent clan names (in which the same totemic clans have names in neighbouring language groups; Jackson 1974) was until the mid-twentieth century an important resource for assimilating newcomer populations in situations of political flux and inter-ethnic mixing.

${ }^{2}$ For Loma, as for their Kpelle and Mende neighbours, this founder is usually said to be a hunter (often an elephant hunter) who found good hunting grounds on what was to become the village site, established a farming/hunting hamlet there for his family, and was eventually followed by others who made the place grow into a village (cf. Leopold 1991: 161).

${ }^{3}$ It would still be important for the host to present the newcomer to the eldest member of the landowning lineage or someone else who could stand in for him in terms of protocol (e.g. the town chief, usually also of the landowning lineage).

${ }^{4}$ These are the terms used by Hubert and Mauss in their 1898 essay on sacrifice. Translator W.D. Halls defines the sacrifiant as 'the subject to whom the benefits of sacrifice accrue ... or who undergoes its effect' (Hubert \& Mauss 1964 [1898]: ix). The sacrifiteur is the person who performs the sacrifice.

${ }^{5}$ Højbjerg (1999) points out that sacrifices having to do with funerals, ancestral propitiation, and the inauguration of a new house do require the daabenui. Sacrifices for the benefit of the village draw upon the idiom of 'taalaabe' and 'taal $\varepsilon k \varepsilon$ ' ('village $k \varepsilon k \varepsilon$ and daabe'). Those performed within some water cults (as Højbjerg mentions) and other power associations may not always enlist the daabe. There is also a category of individual sacrifices, often based on divination, that should be performed with the help of an intermediary, but not necessarily a 'nephew'.

${ }^{6}$ A practice common to the entire Upper Guinea Coast, as Brooks (1993) and others describe.

${ }^{7}$ On wealth-in-people, see Bledsoe (1980); Guyer (1993); and Murphy \& Bledsoe (1987).

${ }^{8}$ I contributed many hours of agricultural labour to my hosts and friends during the period of my research in Giziwulu, though my mediocre agricultural skills placed a limit on the usefulness of my contribution.

${ }^{9}$ Their village history digs up all these contradictions by going back only three generations from the then-current chief.

${ }^{10}$ This echoes Keith Basso's (1970) powerful analysis of silence amongst Western Apache.

${ }^{11}$ It was an exception because I was treated to the full gamut of divergent (though not contradictory) versions of the chieftaincy's settlement.

${ }^{12}$ This is not to say that they will do so. Often enough, they will, in a joking way. In other instances the first impression may be that there is a clear hierarchical $k \varepsilon k \varepsilon$-daabe relation between the two, and only later, in a passing comment or even whispered innuendo, does it come out that the relation is more complicated than it originally seemed.

${ }^{13}$ Both place names and people's names in these examples are pseudonyms. 
${ }^{14}$ Leopold classes these exchanges as 'classic joking relations' (R.S. Leopold, pers. comm., May 2003). This is true among people originating from the same village or chiefdom, but the relations do not translate to more encompassing fields (like regional inter-clan relations), as with northern Mande-speakers and most other African joking relations (e.g. Labouret 1934; Radcliffe-Brown 1952: 90).

${ }^{15}$ The practice of pawning, common among Loma-speakers in Guinea until it was banned in 1947 (along with colonial forced labour), consisted in offering a person to one's debtor to work for them until the time that a debt was fully paid. Their labour was the interest paid on the debt. In many cases, $k \varepsilon k \varepsilon$ offered their daabe as pawns rather than their own children. Schwab writes of Loma pawnship as he observed it in 1928:

[I]t was customary among them to give one's nephew, rather than one's own son. But the chief of Pandemai, when 'hard up', gave his own son rather than take another man's ... Sometimes it was done to obtain rice or cloth, sometimes as a surety for an obligation. When so given, they became the property (slaves) of the one with whom they were left until redeemed (1947: 439).

${ }^{16}$ I have seen a wide range of reactions to such affairs, ranging from an adulterous woman's brothers beating her and forcing her to return to her husband under threat of greater violence, to a kind of shrugging of shoulders all around and a quick dissolution of the original marriage.

${ }^{17}$ I use the term 'bridewealth' provisionally. Loma-speakers describe it more as a series of gifts and possibly also some work for the wife's father. One key informant told me, 'In my opinion, a nephew has to work for his uncle because the uncle has lost his sister [or daughter]. It's a kind of compensation'. The same friend said to me about Loma marriage payments,

It must not be too little, so that the girl's family will say, 'You have had our daughter for nothing. There is a matter of respect for the girl, and also the fact that the family is losing an able-bodied person. But then it cannot be too much, either, so that someone says, 'See, they bought that woman' (J. Onivogui, pers. comm., September 2002).

${ }^{18}$ This is also the situation described by Schwab for 1920s Liberia (1947: 441).

${ }^{19}$ See Højbjerg (1999) for a discussion of similar interactions in the Loma-speaking region of Guinea.

${ }^{20} \mathrm{Cf}$. Mariane Ferme's powerful discussion of the traces of destroyed villages that can be found in eastern Sierra Leone, as in southeastern Guinea, as one walks along bush paths (2001: 40).

${ }^{21}$ The precarity of the deal from the point of view of the conquered is mirrored in the practice of vulnerable families giving daughters in marriage to warlords. This is a practice described both from the period of precolonial inter-village wars and in the context of the wars of the 1990s (Utas 2003). This practice, which ostensibly placed powerful warlords in the position of obsequious wife-receiving daabenui, did not in fact place the warlords 'under the thumbs' of the many families that offered them wives. It may have been calculated to mitigate the level of brutality shown to the bride's family, or perhaps even her village. Utas (2005) describes families explicitly making this calculation during the first Liberian civil war.

${ }^{22}$ It is likely, though difficult to prove, that many of these dynamics have a history going back to the fifteenth or sixteenth century. I emphasize the second half of the nineteenth century because the combination of oral historical and written materials gives us a fairly detailed picture of warfare during this period. However, the broad political economic conditions that applied then were effectively the same as they had been since c.1500: the inter-village slave-raiding wars encouraged by the Atlantic slave trade. The Upper Guinea Coast region actually sent far more people into the trade in the seventeenth and eighteenth centuries than in the nineteenth. Still, there is little to help us establish with certainty whether the microsociology of managing this turbulent period was similar to what we can reconstruct for the nineteenth and early twentieth centuries.

${ }^{23}$ A much higher percentage of Sierra Leonean refugees settled in camps, though many, especially Kissi-, Kuranko-, and Sosso-speakers who were able to find communities speaking their languages on the Guinean side of the border, still self-settled. Several Guinean villages and towns had what they called 'camps', though these were typically just new neighbourhoods added on to existing villages.

${ }^{24}$ Leopold enlarges upon this point (1991: 261-73). One of the primary aspects of the relation that southern Loma-speaking women emphasized to me was that of 'Toboli', which can mean both 'co-wife' and 'Mother's Brother's wife' for a woman. In practice, Toboli resembles a classic joking relationship.

${ }^{25}$ In 'Laughter at marriage: subversion in performance', Karp (1988) describes the experience of the 'patrilineal puzzle' by women in patrilineal societies (who move outside their own patrilineages to reproduce another), just as men in matrilineal societies have long been said to face a 'matrilineal puzzle' (Richards 1950). 


\section{REFERENCES}

Ardener, E. 1975. Belief and the problem of women. In Perceiving women (ed.) S. Ardener, 1-17. London: Malaby Press.

BACHOFen, J.J. 2008 [1861]. An English translation of Bachofen's Mutterrecht (Mother Right) (1861): a study of the religious and judicial aspects of gynecocracy in the ancient world: 'Lycia', 'Crete', and Athens (trans. D. Partenheimer). Lewiston, N.Y.: Edwin Mellen Press.

BAsso, K. 1970. 'To give up on words': silence in Western Apache culture. Southwestern Journal of Anthropology 26, 213-30.

Bledsoe, C.H. 1980. Women and marriage in Kpelle society. Stanford: University Press.

BLoch, M. 1973. The long term and the short term: the economic and political significance of the morality of kinship. In The character of kinship (ed.) J. Goody, 75-87. Cambridge: University Press.

— \& D. Sperber 2002. Kinship and evolved psychological dispositions: the Mother's Brother controversy reconsidered. Current Anthropology 43, 723-34.

BrooKs, G.E. 1993. Landlords and strangers: ecology, society, and trade in Western Africa, 1000-1630. Boulder, Colo.: Westview.

Coulter, C. 2009. Bush wives and girl soldiers: women's lives through war and peace in Sierra Leone. Ithaca, N.Y.: Cornell University Press.

Currens, G.E. 1972. The Loma avunculate: an exercise in the utility of two models. Ethnology 11, 111-21.

D'Azevedo, W.L. 1962. Uses of the past in Gola discourse. The Journal of African History 3, 11-34.

Ferme, M.C. 2001. The underneath of things: violence, history, and the everyday in Sierra Leone. Berkeley: University of California Press.

Finnstrom, S. 2008. Living with bad surroundings: war, history, and everyday moments in northern Uganda. Durham, N.C.: Duke University Press.

Geschiere, P. 2009. The perils of belonging: autochthony, citizenship, and exclusion in Africa and Europe. Chicago: University Press.

Goody, J. 1959. The Mother's Brother and Sister's Son in West Africa. Journal of the Royal Anthropological Institute 89, 61-88.

Guyer, J. 1993. Wealth in people and self-realization in Equatorial Africa. Africa 28, 243-65.

Нøjвjerg, C.K. 1999. Loma political culture: a phenomenology of structural form. Africa 69, 535-54.

Hubert, H. \& M. Mauss 1964 [1898]. Sacrifice: its nature and functions. Chicago: University Press.

JACKson, M. 1974. The structure and significance of Kuranko clanship. Africa 44, 397-415.

2004. In Sierra Leone. Durham, N.C.: Duke University Press.

KARP, I. 1988. Laughter at marriage: subversion in performance. Journal of Folklore Research 25: 1-2, 35-52.

Labouret, H. 1934. Les Toma, Loma ou Logoma. Anthropologie 44, 723-4.

LeACH, E. 1954. Political systems of highland Burma: a study of Kachin social structure. London: G. Bell.

Leopold, R.S. 1991. Prescriptive alliance and ritual collaboration in Loma society. Unpublished Ph.D. dissertation, University of Indiana.

McGovern, M. 2004. Unmasking the state: developing modern political subjectivities in 2oth-century Guinea. Unpublished Ph.D. dissertation, Emory University.

MalinowsKi, B. 1992 [1948]. Magic, science and religion and other essays. Chicago: Waveland Press.

Murphy, W. 1990. Creating the appearance of consensus in Mende political discourse. American Anthropologist 92, 24-41.

\& C.H. Bledsoe 1987. Kinship and territory in the history of a Kpelle chiefdom (Liberia). In The African frontier: the reproduction of traditional African societies (ed.) I. Kopytoff, 121-47. Bloomington: Indiana University Press.

RADCLIFFE-Brown, A.R. 1952. Structure and function in primitive society: essays and addresses. Glencoe, Ill.: Free Press

Richards, A. 1950. Some types of family structure amongst the Central Bantu. In African systems of kinship and marriage (eds) A.R Radcliffe-Brown \& D. Forde, 207-51. London: Oxford University Press.

SAhlins, M. 2011. What kinship is (part one). Journal of the Royal Anthropological Institute (N.S.) 17, 2-19.

SARro, R. 2009. The politics of religious change on the Upper Guinea Coast: iconoclasm done and undone. Edinburgh: International Africa Institute.

Schwab, G. 1947. Tribes of the Liberian hinterland. Cambridge, Mass.: Harvard University Press.

ScOTT, J. 2009. The art of not being governed: an anarchist history of Upland Southeast Asia. New Haven: Yale University Press.

Utas, M. 2003. Sweet battlefields: youth and the Liberian Civil War. Ph.D. dissertation, Uppsala University. 
2005. Victimcy, girlfriending, soldiering: tactic agency in a young woman's social navigation of the Liberian war zone. Anthropological Quarterly 78, 403-30.

Wagner, R. 1977. Analogic kinship: a Daribi example. American Ethnologist 4, 623-42.

\section{La vie en temps de guerre : parenté par désir et gestion de l'insécurité}

Résumé

L'article explore la manière dont l'institution de la parenté avunculaire a été employée comme idiome pour négocier les déplacements forcés, les dépossessions et l'insécurité dans la région forestière où convergent aujourd'hui les frontières de la Guinée, du Liberia, de la Sierra Leone et de la Côte d'Ivoire. Il analyse la manière dont les droits et responsabilités inhérents à la relation entre oncle maternel et neveu par sa mère (MB-ZS) peuvent être invoqués et souhaités par ceux qui n'avaient jusque là aucun lien de parenté mais aussi niés par ceux qui devraient, en principe, être obligés par cette relation. Cette latitude suggère que la parenté avunculaire telle qu'elle se conçoit dans cette région peut être comprise comme l'un des idiomes servant à légitimer les droits revendiqués sur les autres, comme cela arrive souvent dans des périodes d'incertitude et d'instabilité. Plutôt que de traiter cette relation comme une institution sociale qui aurait toujours préexisté, l'auteur suggère qu'elle est aussi le produit d'un vécu historique de guerres, de déplacements et de fuites incessants.

Mike McGovern is Associate Professor of Anthropology at the University of Michigan. He is the author of Making war in Côte d'Ivoire (University of Chicago Press, 2011) and Unmasking the state: making Guinea modern (University of Chicago Press, 2012).

101 West Hall, Department of Anthropology, 1085 S. University Avenue, Ann Arbor, MI 48108-1079, USA. mmcgov@umich.edu 